\title{
Cell Adhesion Molecules and Signal Transduction
}

\author{
細胞接着分子とシグナル伝達 \\ Jaramillo, Maria L.; and Bell, J.C. \\ Departments of Medicine and Biochemistry, University of Ottawa \\ Ottawa, Ontario, Canada K1H 8M5, FAX: 1-613-247-6897
}

Key Words: cell adhesion molecules, myelin associated glycoprotein, nervous system, signal transduction

\begin{abstract}
Cell adhesion molecules (CAM) play key roles in the fundamental processes of growth and development, particularly in the nervous system. This review focuses on the evidence implicating the cadherin, integrin and immunoglobulin superfamily of cell adhesion molecules in various signal transduction pathways. In addition to modulating cell adhesion and migration, CAMs also serve to directly regulate the response to growth and differentiation factors. This review focuses on the role of CAMs and their signal transduction pathways, where known, in several developmentally regulated processes in the nervous system such as the induction of neural tissue, neuroblast migration, axon growth and guidance, and myelination.
\end{abstract}

要 約

細胞接着分子 $(\mathrm{CAM})$ は、細胞増殖や個体発生の重要な過程 で、特に神経系において重要な役割を果している。この総説で は、細胞接着分子であるカドヘリン、インテグリンおよび免疫 グロブリンスーパーファミリーとさまざまなシグナル伝達系と の関係に関する証拠を対象とする。また、CAMの働きは細胞接 着や移動を調節するだけでなく、細胞增殖や分化因子に対する 応答も直接調節する。この総説は神経誘導、神経芽細胞の移 動、軸索の成長と誘導拉よびミエリン化のような、神経系にお ける多くの発生過程の調節で、CAMとそのシグナル伝達系の果 たしている役割に関する知見に焦点を合わせている。

\section{A. Introduction}

Cell adhesion molecules or CAMs comprise a category of macromolecules which share a common feature of providing a physical link between adjacent cells or cells and the extracellular matrix. In addition to this basic function, CAMs also serve to couple signalling pathways involved in information transfer from the extracellular milieu to the cell. CAMs serve an essential role in several primary processes in development. The organization of form and pattern is conditional upon initial cellto-cell interactions established early during development(1), particularly in the nervous system (2-4).

This review focuses on three major classes of CAMs (cadherins, integrins and CAMs belonging to the immunoglobulin (Ig) supergene family) and the roles that they play in development of the nervous system. This includes several developmentally regulated processes including the induction of neural tissue, neuroblast migration, axon growth and guidance, and myelination. Although the nature of how such cell-cell interactions are transduced into these complex morphological responses is not fully clear, wherever possible the signal transduction pathways involved will be emphasized. Examples of signal transduction pathways will involve inside-out signalling

\section{A. はじめに}

細胞接着分子、寸なわちCAMは、隣接した細胞-細胞間や 細胞-細胞外基質間を物理的に結合させることを共通の性質とす る巨大分子に分類される。CAMはこの基本的な機能に加え、細 胞外環境から細胞へのシグナル伝達経路を仲介する働きもあ る。CAMは個体発生のさまざまな初期過程において非常に重要 な役割を果たしている。形態形成やパターン形成は、初期発生 過程(1)、特に神経系(2-4)において確立される初期の細胞-細胞間 相互作用に依存している。

この総説は、3種類の主要なCAM(カドヘリン、インテグリ ンおよび免疫グロブリン $(\mathrm{Ig})$ スーパーファミリーに属するCAM) の、特に神経系の発生におけるCAMの役割に焦点を絞った。こ れには神経誘導、神経芽細胞の移動、軸索の成長と誘導及びミ エリン化などの、発生過程に扔いて調節されるさまざまな過程 がある。どのようにして細胞-細胞間相互作用がその複雑な形態 的な応答へと伝達されるのかについての本態は、あまり明確に なってないが、分かっている限りのシグナル伝達経路のかかわ りを述べるつもりである。シグナル伝達経路の例として、次の ようなものがある。細胞内から細胞外へのシグナル伝達では細 胞内のできごとにより細胞外のリガンドの結合が調節される

Abbreviations: CAM, cell adhesion molecule; EGF, epidermal growth factor; FGF, fibroblast growth factor; NGF, nerve growth factor; FAK, focal adhesion kinase; N-CAM, neural cell adhesion molecule; MAG, myelin-associated glycoprotein. 
in which binding to extracellular ligands can be modulated by intracellular events, and outside-in signalling in which the extracellular ligand and/or environment influences gene regulation and cell growth or differentiation.

\section{B. Cadherins and Early Embryonic Development}

Cadherins are a family of calcium-dependent cell-cell adhesion molecules which are found on the surface of most cell types [reviewed in (5-7)]. These molecules mediate homophilic (like-with-like) adhesion between cells. At a given developmental stage, most tissues express only a single cadherin subtype. The three best characterized members of the family include $\mathrm{E}$ (epithelial)-cadherins, $\mathrm{N}$ (neural) cadherins and $\mathrm{P}$ (placental) cadherins, named from the tissue type in which they were originally detected. Numerous (more than 15) different cadherin molecules are now known [see $(7,8)]$. In addition to $\mathrm{R}$ (retinal)-cadherin (9) and B-cadherin (10), several cDNAs encoding novel cadherins have been identified by RT-PCR from brain RNA(11). Cells that express different cadherins are capable of adhering preferentially to their own cell class (12). As a result of their role in cell sorting, cadherins are considered to be important regulators of morphogenesis and tissue morphology $(5,13)$.

Different members of the cadherin family have distinct spatial and temporal patterns of expression during embryonic development $(13,14)$. E-Cadherin is expressed when embryonic transcription starts and is responsible for compaction of the morula (15). N-Cadherin, (as well as P-cadherin or Rcadherin in some cell types) becomes the major cell adhesion molecule expressed following differentiation of the CNS from the neural tube. $\mathrm{N}$-Cadherin expression is lost as neural crest cells begin migration, however, upon reaching their final destination, they differentiate into various cell types, including neurons and glia, and regain $\mathrm{N}$-cadherin expression.

\section{B-1. Cadherins Require an Extracellular and Cytoplasmic Domain}

Cadherins are integral membrane glycoproteins which contain a large extracellular domain responsible for calciumdependent binding and recognition as well as a highly conserved cytoplasmic tail [see Fig. 1, ref(16)]. The classical cadherins have an ectodomain composed of four homologous structural repeats, with binding specificity localized to the most distal repeat (17). The cytoplasmic tail is necessary for cell-cell binding (18) and links cadherins to the actin cytoskeleton by binding catenins $(19,20)$. The importance of both the extracellular and intracellular domain in cell adhesion during embryonic development is supported by microinjection studies in Xenopus laevis embryos. Ectodermal lesions were observed in early Xenopus embryos following expression of a dominantnegative mutant of E-cadherin which lacked the cytoplasmic tail (21). This phenotype was in contrast to that obtained upon
し、また、細胞外から細胞内へのシグナル伝達においては細胞 外のリガンドや環境が遺伝子の制御、細胞增殖や分化に影響を 与える。

B. カドヘリンと初期発生

カドヘリンはほとんどの型の細胞表面に見られるカルシウ 厶依存性細胞-細胞間接着因子ファミリーに属している(総説参照 (5-7)。これらの分子は、細胞どうしをホモフィリック(仲間ど うしの結合)な接着によって仲介する。発生過程のそ机ぞ机の段 階において、ほとんどの組織はただ1種類のカドへリンを発現 している。最も詳細に研究されているカドへリンファミリーに 属する3種類の分子は、それぞれ発見された組織(臓器)にちなん で、 $\mathrm{E}$ (上皮)-カドヘリン、 $\mathrm{N}$ (神経)-カドヘリン、 $\mathrm{P}$ (胎盤)-カド ヘリンと名付けられている。多く(15種類以上)のカドヘリンが 今では知られている((7、8)を参照)。さらに、 $\mathrm{R}$ (網膜)-カドへリ ン(9)、B-カドヘリン(10)をはじめ数種類の新規なカドヘリンの cDNAが、脳のRNAからRT-PCR法によって同定されている (11)。何種類かのカドヘリンを発現している細胞を混合する と、同種のカドヘリンを発現する細胞どうしが選択的に接着す る(12)。細胞選別における役割からわかるように、カドヘリン は形態形成や組織構築の重要な調節因子であると考えられる(5、 13)。

カドヘリンのそれぞれの種類は、胚の発生過程において時 間的、空間的に特徵的な発現パターンを示す $(13 、 14)$ 。E-カドへ リンは胚性の転写が始まる時から発現し、桑実胚のコンパク ションを引き起こす(15)。N-カドへリン(一部の細胞に扔いて は、P-カドヘリンやRーカドヘリンも同様である)は神経管から中 枢神経系への分化にともなって発現する主要な細胞接着分子で ある。N-カドヘリンの発現は神経堤細胞の移動が始まるととも に消失するが、しかるべき場所に到達して、神経細胞やグリア のようなさまざまな細胞に分化すると、再びN-カドヘリンを発 現するようになる。

\section{B-1. カドヘリンには細胞外と細胞内ドメインが必要である}

カドヘリンは膜貫通型の糖タンパク質で、カルシウム依存 性の結合をつかさどる大きな細胞外ドメインと、非常に良く保 存されている細胞質ドメインから構成されている[図1参照、 (16)。典型的なカドヘリンは4つの繰り返し構造から構成され る外部ドメインを有し、その結合特異性は最も外側の繰り返し 単位に存在する(17)。細胞質ドメインは細胞-細胞間の結合に必 須であり(18)、カテニンによってアクチン細胞骨格とカドへリ ンをつなぎとめる(19、20)。肧発生猧程に扔けるカドヘリンの細 胞外ドメインおよび細胞内ドメインの重要性は、アフリカッメ ガエル肧を用いたマイクロインジェクション法による研究に よって支持されている。初期発生過程のアフリカツメガエル胚 に、細胞質ドメインを欠損したドミナントネガティブE-カドへ リン変異体を発現させると、外胚葉に欠皕が生じた(21)。この 


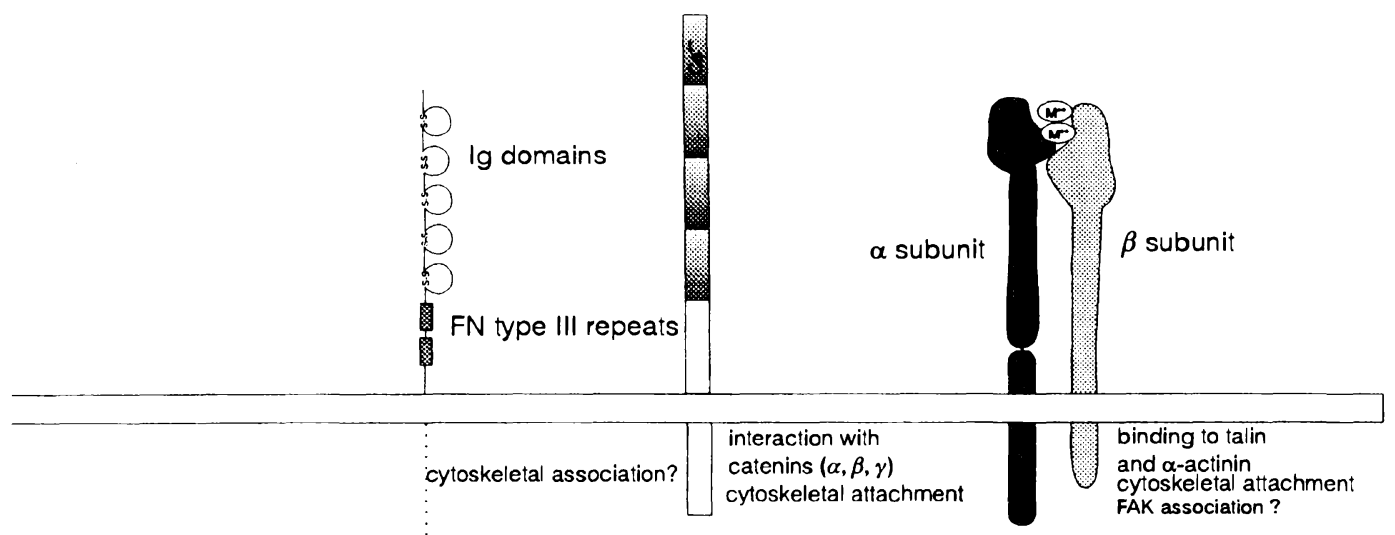

\begin{tabular}{|c|c|c|c|}
\hline GENERAL FEATURES & Ig superfamily & Cadherins & Integrins \\
\hline subunit structure & monomer & monomer & $\begin{array}{l}\text { heterodimer } \\
(\alpha, \beta)\end{array}$ \\
\hline members & many ${ }^{*}$ & $>15$ & $\begin{array}{l}>20 \text { combinations } \\
(8 \alpha, 15 \beta)\end{array}$ \\
\hline binding & $\begin{array}{l}\text { homophilic and/or } \\
\text { heterophilic }\end{array}$ & homophilic & $\begin{array}{l}\text { heterophilic } \\
\text { binding to ECM glycoproteins }\end{array}$ \\
\hline $\begin{array}{l}\mathrm{M}^{++}\left(\mathrm{Ca}^{++}, \mathrm{Mg}^{++}, \mathrm{Mn}^{++}\right) \\
\text {dependence }\end{array}$ & no & yes $\left(\mathrm{Ca}^{++}\right)$ & yes \\
\hline
\end{tabular}

Fig. 1. Structural features of cell adhesion molecules and their binding properties (table above). The role of the cytoplasmic tail (where known) is marked. Immunoglobulin-related CAMs contain Ig domains (open circles) flanked by disulfide bridges and may contain fibronectin typeIII repeats (hatched rectangles) in their extracellular domain. Ig-like CAMs may also contain transmembrane and cytoplasmic domains (dotted line), or be linked to the plasma membrane by a phosphatidylinositol linkage. *Additional structural diversity can be generated by alternative splicing. Cadherins are cell-cell adhesion molecules which contain three to five homologous repeats (hatched rectangles) in their extracellular domain, of which the most distal is involved in binding specificity, as well as a conserved cytoplasmic domain. Integrins are composed of heterodimers which recognize extracellular matrix glycoproteins. See text for details [adapted from ref (2)].

injection of the highly conserved cytoplasmic tail and transmembrane domain of $\mathrm{N}$-cadherin which resulted in a dramatic inhibition of cell adhesion in the resultant embryo (22), presumably by competition for cytoplasmic factors which recognize the cytoplasmic tail and are necessary for cell adhesion by all cadherin subtypes.

\section{B-2. Outside-in Signalling in Cadherins}

Upon cell adhesion, the signal obtained following binding of the extracellular domain is transferred to the cytoplasmic domain, resulting in the assembly of a multi-component complex [reviewed in $(16,23)]$. One of the cytoplasmic factors which associates with cadherins is $\alpha$-catenin, a molecule related to vinculin. Its importance in mediating cadherin function is demonstrated by the fact that cells expressing cadherin but lacking $\alpha$-catenin are non-adherent(24). Other molecules include $\beta$-catenin which is related to armadillo (arm) (25), an epidermal gene product involved in segment polarity of the Drosophila cuticle via the wingless $(w g)$ signalling pathway $(26,27)$. Although the mechanism by which ( $\beta$-catenin and) arm function asintracellular developmental signalling molecules is not clear, it appears that the response to Wnt(a mammalian homolog of $w g$ ) results in modulation of cell adhesion in cultured cells (28). Another molecule loosely associated with
表現型は、N-カドヘリンの非常に良く保存された細胞質ドメイ ンと膜貫通ドメインを注入した結果として、細胞接着が劇的に 阻害された肧の表現型と対照的である(22)。おそらく、細胞質 ドメインを認識し、すべての種類のカドヘリンで細胞接着に必 須な細胞質因子との競合によって起きたのだろう。

\section{B-2. カドヘリンによる細胞外から細胞内へのシグナル伝達}

細胞接着に拀いて細胞外ドメインの結合によって生じたシ グナルは細胞質ドメインへと伝達され、多分子複合体の形成が 起こる(総説参照16、23)。カドヘリンと結合している細胞質因 子の一つは、ビンキュリンに類似した分子、 $\alpha$ カテニンであ る。カドヘリンを発現していても、 $\alpha$ カテニンを欠損する細胞 は非接着性であることから、カドへリンの機能を介在するカテ ニンの重要性が証明された(24)。その他の分子として、アルマ ジロ $(\mathrm{arm})$ と類似するアカテニンが存在する $(25)$ ○これは、クチ クラの遺伝子産物で、ウイングレス $(w g)$ のシグナル伝達経路を 経てショウジョウバエのクチクラの体節の細分化に必要である (26、27)。Wnt(wgの哺乳類のホモログ)と反応して培養細胞では 細胞接着が調節されるが、細胞内の発生シグナル伝達分子とし てのßカテニンと $\mathrm{arm}$ の機能を説明しうる機構は明らかではな い(28)。カドヘリンとゆるく結合する他の分子として $\gamma$ カテニ ンが存在する。 $\gamma$ カテニンは、デスモソーム接着分子と結合し 
cadherins is $\gamma$-catenin, a protein similar, if not identical to plakoglobin, which is known to associate with desmosomal adhesion molecules.

Other proteins have been found to be associated with catenins, including the APC gene product, a tumor suppressor gene linked to familial adenomatous polyposis $(29,30)$. Since mutations of this gene are believed to be involved in progression of sporadic colorectal and gastric tumors, it may be that cadherins regulate cell proliferation and differentiation as well as cell adhesion (31).

\section{B-3. Inside-out Signalling in Cadherins}

The ability of cadherins to function as cell adhesion molecules can be regulated under certain conditions. It appears that $\beta$-catenin is frequently a target for signal transduction pathways [see (26)]. In responsive cells, treatment with Wnt-1, results in increased cell adhesion, presumably by stabilizing cadherin/ $\beta$-catenin complexes (28). Cadherin mediated adhesion can also be increased, resulting in premature compaction at the four cell stage, following treatment of embryos by activators of protein kinase $\mathrm{C}(32)$. In contrast, cadherin-mediated adhesion and cell mobility is decreased as a result of the tyrosine phosphorylation of cadherins and catenins by v-src (33, 34). Tyrosine phosphorylation of catenins was also observed in cells treated with hepatocyte growth factor and epidermal growth factor (EGF) (35). Recently, the EGF receptor was shown to associate with cadherin-catenin complex and result in the tyrosine phosphorylation of $\beta$ and $\gamma$-catenin (36). Although the biological significance of this is not clear, tyrosine phosphorylation resulted in an altered distribution (36), suggestive of a disassembly of the cadherin-catenin complex from the actin filament network.

\section{Integrins and the Extracellular Matrix in Neuronal De- velopment}

Integrins are another major class of adhesion molecules. These receptors consist of heterodimers composed of an $\alpha$ and a $\beta$ subunit (Fig. 1). Unlike the cadherin and immunoglobulin supergene family members, the majority of integrins are involved in cell-matrix interactions during cell adhesion to basement membrane and extracellular matrix (ECM) [reviewed in $(37,38)]$. In certain cell types, however, integrins mediate heterophilic adhesion(like-with unlike, or adhesion between different CAM members) with receptors of the Ig superfamily (ICAM-1 or -2, VCAM) on the surface of lymphoid cells (39).

The specificity of the integrin interaction with various ECM components is defined by the particular $\alpha$ and $\beta$ combination. Over $20 \alpha / \beta$ combinations are presently known for the eight $\beta$ and fourteen $\alpha$ subunits described to date (38), although several integrins are capable of recognizing the same ECM molecule, albeit at different sites (40). The large extracellular domains in both $\alpha$ and $\beta$ subunits together form the divalent
ていることが知られているプラコグロビンと類似しているが、 別の分子である。

カテニンと結合するタンパク質がいくつか発見されてお り、その一つであるAPC遺伝子産物は家族性腺腫性茸腫症に関 係する癌抑制遺伝子である(29、30)。この遺伝子の変異が散発 性結腸癌と胃癌の進行にかかわっていると考えられていること から、カドヘリンは細胞接着と同様に細胞の增殖や分化をも調 節しうる可能性がある(31)。

\section{B-3. カドヘリンによる細胞内から細胞外へのシグナル伝達}

細胞接着分子として機能するカドヘリンの能力は、ある状 態の下では制御されている。ßカテニンはしばしばシグナル伝 達経路の標的となると思われている(26)。Wnt-1処理によって細 胞接着が増加するが、拉そらくカドヘリン/ßカテニン複合体の 安定化によるものであろう(28)。プロテインキナーゼCの活性化 因子を胚に作用させると、カドヘリンを介した細胞接着が増加 し、4細胞期に不完全なコンパクションを引き起こす(32)。対照 的に、v-srcによってカドヘリンとカテニンのチロシンがリン酸 化されると、カドヘリン依存的な細胞接着や細胞運動能が減少 する(33、34)。カテニンのチロシンリン酸化は、肝細胞成長因 子(HGF)や上皮成長因子(EGF)で処理された細胞において観察さ れている(35)。最近、EGFレセプターがカドヘリンーカテニン複 合体と会合することで、乃一及び $\gamma$-カテニンがチロシンリン酸化 されることが示された(36)。その生物学的な意義は明確でない が、チロシンリン酸化がさまざまな分布を示すこと(36)から、 アクチン繊維のネットワークからカドヘリン-カテニン複合体を 解離させることを示唆する。

\section{C. 神経発生におけるインテグリンと細胞外基質}

インテグリンもまた主要な細胞接着分子の一つである。こ の分子は $\alpha$ と $\beta$ サブユニットのヘテロダイマーから構成されて いる(図1)。カドヘリンや免疫グロブリンスーパーファミリーの 分子とは異なり、主要なインテグリンは基底膜や細胞外基質 (ECM)に対する細胞接着の過程において細胞-基質間の相互作用 に必要である(総説参照37、38)。しかし、ある細胞種における インテグリンは、リンパ細胞の細胞膜に存在する免疫グロブリ ンスーパーファミリーのレセプター(ICAM-1/-2、VCAM)とへテ ロフィリック(異なる分子間の結合)な接着を形成する(39)。

さまざまなECM成分とインテグリンとの相互作用の特異性 は、特定の $\alpha$ サブユニットと $\beta$ サブユニットの組合せによって 規定される。今までに、8種類の $\beta$ サブユニットと 14 種類の $\alpha$ サ ブユニットから、20種類以上の $\alpha / \beta$ サブユニットの組合せが構 成されることが明らかとなっており(38)、多くのインテグリン は、異なる部位ではあるが、同じECM分子を認識しうる(40)。 ๙とßサブユニットの大きな細胞外ドメインどうしは、ECM分 
cation-dependent $\left(\mathrm{Ca}^{++} . \mathrm{Mg}^{++}\right.$or $\mathrm{Mn}^{++}$, depending on the subtype) binding domain for the ECM molecule or Ig-like cell surface receptor. Since most cells recognize more than one ECM protein, the adhesiveness for selective ECM components is regulated in part by the relative expression levels of their corresponding receptors. These adhesive extracellular components include molecules such as fibronectins and laminins. For several ECM components, including fibronectin, recognition of the tripeptide of the sequence Arg-Gly-Asp (RGD) on the ECM molecule (or other short peptide sequence) is important for binding to integrins to occur (40-42).

In addition to the role that cell-cell adhesion molecules, such as N-cadherin and N-CAM (discussed later) play in regulating interactions between neuronal cells during development, many ECM molecules also play important roles in development $(43,44)$, primarily in cell migration and differentiation, through the interaction of integrins. The ECM matrix glycoproteins, especially fibronectin and laminin, promote the adhesion and migration of neural cells, in particular those of the neural crest. ECM molecules and their receptor integrins have also been implicated in the regulation of neurite outgrowth and guidance (3, 45).

\section{C-1. Inside-out Signalling in Integrins}

Integrin function can be regulated by several mechanisms. As well as the modulation of subunit expression levels, integrins can exist in different extracellular ligand affinity states which can be modified by intracellular signals. Treatment of platelets with activating agents such as thrombin, epinephrine or ADP, induces a conformational change in the integrin GPIIb-IIIA (also known as $\alpha_{1 \mathrm{ll}} \beta_{3}$ ), which confers high-affinity plasma fibrinogen binding and subsequent aggregation of platelets [reviewed in $(46,47)$ ]. The nature of the change that confers high-affinity ligand binding to a low-affinity state is not clear, however, it appears that the cytoplasmic region of the $\alpha$ subunit is necessary for the constitutive inactive state. Similarly, activation of $\beta_{2}$ leukocyte integrins by immune or inflammatory mediators involves ligand affinity changes through altered conformation of the integrin extracellular domain (48). The conformational changes induced by ligand binding may involve release of the $\beta$ subunit cytoplasmic domain from an inhibitory effect caused by the $\alpha$ subunit (49). Although the affinity modulation of integrin receptors is not well understood, factors that have been implicated in this process include intracellular $\mathrm{Ca}^{++}, \mathrm{G}$ proteins and protein kinases.

\section{C-2. Outside-in Signalling in Integrins}

The intracellular domain of the $\beta$ subunit has been shown to be associated with the actin cytoskeleton and is responsible for the localization of integrins to focal adhesions $(23,50)$, specialized junctions between cells and the substratum featuring clustering of integrins. Components of the focal adhesion plaques include vinculin, $\alpha$-actinin and talin, of which
子や $\operatorname{Ig}$ 様細胞表層レセプターに対する二価陽イオン $\left(\mathrm{Ca}^{++} 、\right.$

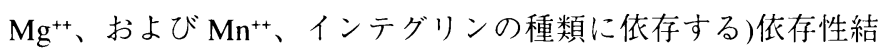
合ドメインを形成する。ほとんどの細胞は1種類以上の ECM 夕 ンパク質を認識し、特定の ECM 成分との接着性はそれぞれに 対応したレセプター間の相対的な発現量によって調節されてい る。これらの接着性細胞外成分として、ファイブロネクチンや ラミニンなどの分子が存在する。ファイブロネクチンをはじめ 多くのECM成分に扔いて、ECM 分子(もしくはその他の短い配 列)上に存在するArg-Gly-Asp(RGD)配列トリペプチドの認識は、 インテグリンに結合するために重要である(40-42)。

N-カドヘリンとN-CAMのような細胞-細胞接着分子は、発 生過程における神経細胞間の相互作用の調節で果たしている役 割(後述)のほか、多くのECM分子はインテグリンとの相互作用 を介して、発生系の、特に細胞の移動や分化において重要な役 割を果している(43、44)。細胞外マトリックス糖タンパク質、 特にファイブロネクチンやラミニンは、神経細胞、特に神経堤 細胞の接着や移動を促進する。ECM分子やそのレセプターであ るインテグリンは、神経突起の伸長や誘導の調節にも関与して いる(3、45)。

C-1. インテグリンによる細胞内から細胞外へのシグナル伝達 インテグリンの機能はさまざまな機構によって調節されう る。サブユニットの発現量による調節だけではなく、インテグ リンには細胞内のシグナルによって修飾される細胞外リガンド に対するさまざまな親和状態が存在する。トロンビン、エピネ フリンやADPのような活性化物質で処理された血小板は、イン テグリンGPIIb-IIA( $\alpha_{\text {IIb }} \beta_{3}$ としても知られている $)$ の構造変化を 引き起こす(総説参照46、47)。このインテグリンは、高親和性 血漿ファイブロネクチンの結合と、それに引き続く血小板の凝 集を引き起こす。高親和性リガンドが低親和性状態に結合する ことの変化の本質は明らかでないが、 $\alpha$ サブユニットの細胞質 ドメインは持続的な不活性な状態の維持に必要であることが明 かとなっている。同様に、免疫や炎症の誘起物質によって $\beta_{2} リ$ ンパ性インテグリンの活性化は、インテグリンの細胞外ドメイ ンを別のコンフォメーションにしてリガンドとの親和性を変化 させるために必要である(48)。リガンドの結合によって引き起 こされる高次構造の変化は、 $\alpha$ サブユニットによる阻害効果か らßサブユニットの細胞質ドメインを遊離させるのに必要らし い(49)。インテグリンの親和性の調節はよくわかっていない が、この過程にかかわる因子には、細胞内カルシウムイオン、 Gタンパク質やタンパク質キナーゼがあるだろう。

\section{C-2. インテグリンによる細胞外から細胞内へのシグナル伝達}

アサブユニットの細胞質ドメインはアクチン骨格と結合し ており、接着斑へのインテグリンの局在に対応していることが 示されている(23、50)。接着斑とは細胞-基質間の特別な結合部 位で、インテグリンの集合体が存在する。接着斑の成分には、 ビンキュリン、 $\alpha$-アクチニンおよびタリンが存在するが、タリ 
talin and $\alpha$-actinin have been shown to bind to the integrin $\beta 1$ subunit and mediate attachment to actin filaments. Protein tyrosine phosphorylation has been implicated in the regulation of the assembly of focal adhesions, since focal adhesions contain elevated levels of phosphotyrosine and tyrosine kinase inhibitors have been shown to inhibit focal adhesion assembly and actin stress fiber formation which occur as a result of cell attachment (51). Analysis of focal adhesion following adhesion and spreading on ECM substrate reveals the presence of several tyrosine phosphorylated proteins, including paxillin (a vinculin binding protein) and a tyrosine kinase called FAK, both of which are implicated in the association of integrins to the actin cytoskeleton in the focal contacts $(51,52)$.

Integrins can transduce growth and differentiation signals from the ECM, presumably through the intracellular proteins FAK and paxillin [reviewed in (53-56)]. Paxillin has been shown to interact with c-crk (57), an SH2-SH3 adaptor molecule which is involved in other signalling pathways mediated by growth factor receptors for nerve growth factor (NGF) and epidermal growth factor (58). In addition to being a substrate for $\mathrm{v}$-src, focal adhesion kinase(or FAK), a member of the src family of tyrosine kinases, is also tyrosine phosphorylated in response to various growth factors including bombesin, endothelien and vasopressin $(59,60)$. Activation of FAK kinase activity as a result of its tyrosine phosphorylation, is implicated in the phosphorylation of paxillin and other substrates involved in either differentiation or cell cycle events.

Adhesion to an extracellular matrix is required for progression through the G1 phase of the cell cycle (61), a phenomenon called anchorage dependence. Recent findings have implicated integrin-mediated signalling and the activation of FAK as key regulators in the prevention of apoptosis which ensues when anchorage-dependent cells are denied an ECM substrate (62). FAK and other effector molecules may act to integrate the signalling pathways initiated by both integrins and growth factors. Fibronectin stimulation of NIH3T3 cells was shown to promote FAK tyrosine phosphorylation and its association with signalling molecules, including $\mathrm{c}$-src and the ras exchange factor GRB2 and activation of MAP kinase (63). The activation of MAP kinases has been shown to be dependent on the integrity of the actin cytoskeleton (64).

The mechanism by which FAK activation occurs is not clear, since the cytoplasmic domains of integrins do not contain tyrosine kinase or other catalytic domains. It has been suggested that integrin engagement may reveal a latent cytoplasmic binding site for FAK which would result in its association and activation (49). Alternatively, upon ligand binding, integrins may interact with or activate other transmembrane or cytoplasmic effector molecules capable of activating FAK. In platelets, binding of fibrinogen to the activated $\alpha_{\mathrm{Il}} \beta_{3}$ integrin results in tyrosine phosphorylation of a number of proteins, in-

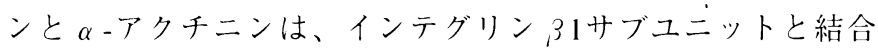

し、アクチン繊維との結合に介在することが示されている。接 着斑ではリン酸化チロシン量が増加するし、また、細胞接着の 結果接着斑の構成とアクチンストレス繊維が形成されるが、こ れはチロシンキナーゼ阻害剤で阻害されることから、タンパク 質のチロシンリン酸化は接着斑の構成の制御にかかわっている ことが示されている(51)。ECM基質上の伸展の結果形成された 接着斑の解析によって、チロシンがリン酸化された多くのタン パク質の存在が明らかとなった。パキシリン(ビンキュリン結合 タンパク質)やFAK(チロシンキナーゼ)はその一例であるが、両 分子ともに接着斑のインテグリンとアクチン骨格が結合してい る部分にかかわっている(51、52)。

インテグリンはECMからの増殖や分化のシグナルを伝達す るが、おそらく細胞内タンパク質であるFAKやパキシリンを介 していると考えられている[総説参照(53-56)]。パキシリンは、 神経成長因子(NGF)や上皮成長因子(EGF)のレセプターによるシ グナル伝達経路において必要であるとされているSH2-SH3アダ プター分子であるc-crk(57)と結合していることが示されている (58)。v-srcの基質であるほか、チロシンキナーゼのsrcファミ リーである接着斑キナーゼ(FAK)は、ボンベシン、エンドセリ ンやバゾプレッシンのようなさまざまな成長因子に応答し、チ ロシン残基がリン酸化される(59、60)。FAKのチロシンがリン 酸化されるとFAKキナーゼは活性化され、分化や細胞周期の調 節に必要なパキシリンをはじめ、さまざまな分子のリン酸化に 関与する。

細胞外基質への接着は細胞周期が $\mathrm{G} 1$ 期に進行するために必 要であり(61)、この現象は「接着依存」と呼ばれている。最近 の知見によると、接着依存性細胞がECM基質を与えられていな い時に起こるアポトーシスの誘導において鍵となる調節因子で あるFAKの活性化と、インテグリンを介したシグナル伝達は関 係しているらしい(62)。FAKと他の効果分子は、インテグリン や成長因子によって生じるシグナル伝達の統合に働く可能性が ある。NIH3T3細胞のファイブロネクチンによる刺激によって、 FAKのチロシンリン酸化を誘導し、シグナル伝達分子であるc$\operatorname{src}$ および ras 変換因子(GRB2) との結合やMAPキナーゼの活性化 が誘導される(63)。MAPキナーゼの活性化は、アクチン骨格の 重合に依存している(64)。

FAKの活性化が起こる機構は明確でない。インテグリンの 細胞質ドメインには、チロシンキナーゼなどの触媒ドメインが 存在しないのである。潜在的なFAKの細胞質結合部位が現われ る結果、インテグリンにFAKが結合してFAKが活性化される可 能性が示唆されている(49)。これとは別に、リガンドが結合す るとインテグリンがFAKを活性化しうる膜貫通型分子や細胞質 分子と相互作用する可能性、もしくはそれらの分子を活性化す る可能性がある。血小板において、フィブリノーゲンが活性化 $\alpha_{\text {Ilh }} \beta_{3}$ インテグリンへ結合すると、FAKをはじめ非常に多くの タンパク質のリン酸化が起こる(47)。トロンボスポンジンのレ 
cluding FAK (47). Following aggregation, coclustering of integrins with other cell membrane proteins, such as the thrombospondin receptor, results in the activation of their associated cytoplasmic tyrosine kinases, leading to the phosphorylation and activation of FAK. Initiation of tyrosine phosphorylation cascades may entail the interaction of integrin receptors with other receptors concomitant with their clustering and association with the cytoskeleton. This may explain why many of the early responses of integrin binding to the ECM are the same as those triggered by growth factors, such as stimulation of $\mathrm{Ca}^{++}$ influxes, cytoplasmic alkalinization and protein tyrosine phosphorylation $(65,66)$. This is similar in mechanism to that observed upon stimulation of the T-cell antigen receptor (67) and may represent a common theme of cellular signalling.

\section{Immunoglobulin Supergene Family of CAMs}

The other major class of cell-cell adhesion molecules consists of members of the immunoglobulin supergene family, characterized by the presence of immunoglobulin (Ig) domains. Each domain encodes a conserved protein structure approximately 100 amino acids in length with two highly conserved regions surrounding cysteine residues about 50-60 amino acids apart. Initially observed on immunoglobulins, these domains are found in a variety of molecules involved in cell surface recognition [Fig. 1, reviewed in (68-70)]. In addition to the Ig domains, members of the Ig superfamily may also contain fibronectin type III repeats, first detected in fibronectin and subsequently identified in a number of cell surface receptors and ECM proteins. Binding typically occurs in a $\mathrm{Ca}^{++}$- independent and homophilic fashion, however, certain Ig-like CAMs are capable of binding heterotypically to other CAMs (e.g. ICAM binding to integrin receptors on endothelial cells) and components of the ECM. The cytoplasmic domains of these molecules vary in length and structure as a result of alternative splicing. Not all Ig CAMs are transmembrane; some are bound to the cell surface through phosphatidyl inositol linkages.

The prototype of Ig-like CAMs, N-CAM was the first CAM isolated from the brain (71)[reviewed in (72)]. The patterns of expression of $\mathrm{N}-\mathrm{CAM}$ and $\mathrm{N}$-cadherin are alike during early development $(73,74)$. Recently, it has been shown that products of homeobox genes may directly modulate the transcription of the N-CAM gene (75). N-CAM expression can be first detected on neural epithelial cells soon after neural induction and is succeeded shortly by uniform expression in the early neural tube. As with $\mathrm{N}$-cadherin, $\mathrm{N}$-CAM disappears from the surface of neural crest cells before their migration and reappears on sensory precursors during gangliogenesis. N-CAM can subsequently be identified on developing neurons and glia as well as muscle and a variety of other tissues (in the adult). Perturbation experiments in vivo and in vitro have suggested a variety of roles for N-CAM in such neural interactions such as
セプターのような、他の細胞膜タンパク質とともに、インテグ リンが凝集してクラスター形成が生じると、FAKのリン酸化と 活性化に引き続いてそれらの分子と結合しているチロシンキ ナーゼの活性化が起こる。チロシンリン酸化のカスケードが流 れ始めることは、インテグリンとその他のレセプターとが結合 することと同時に、クラスターを形成し、細胞骨格と結合する ために必要とされる。これで、なぜECMにインテグリンが結合 した結果生じる多くの初期の応答は、例えば、カルシウムイオ ンの流入や細胞質のアルカリ化やタンパク質のチロシンリン酸 化を刺激するような成長因子により引き起こされる初期の応答 と類似しているのかを説明できるだろう(65、66)。これは、T細胞 の抗原レセプターの刺激(67)や、今までに知られている多くの細 胞のシグナル伝達の共通の主題に見られる機構と類似している。

\section{CAMである免疫グロブリンスーパーファミリー}

その他の細胞-細胞間接着分子として、免疫グロブリン(Ig) ドメインを有する免疫グロブリンスーパーファミリーに属する ものがある。それぞれのドメインは、2つの非常に良く保存され たシステイン残基を取り囲む約50～60残基のアミノ酸領域を含 む、拈よそ100アミノ酸残基から構成される保存されたタンパク 質をコードする。Igドメインがさまざまな細胞表層の認識分子 に見い出されることは、以前より知られていた[図1、総説参照 (68-70)]。さらに、Igスーパーファミリーの分子に存在する $\operatorname{Ig}$ ド メインには、ファイブロネクチンタイプIIIリピートがある。こ のリピートは最初にファイブロネクチンに存在することが見つ かり、その後、多くの細胞表層のレセプターやECMのタンパク 質に含まれていることがわかってきた。Ig様CAMは主にカルシ ウム非依存性のホモフィリックな結合様式を示すが、他のCAM (例えば、ICAMは、内皮細胞のインテグリンと結合する)やECM の構成成分とへテロフィリックに結合しうる。それらの分子の 細胞質ドメインは、オルタナティブスプライシングによって多 様な長さや構造を形成する。すべてのIg CAMが膜貫通型なので はなく、そのいくつかはフォスファチジルイノシトール結合を 介して細胞表層に結合している。

Ig様CAMの原型であるN-CAMは、脳から単離された最初 のCAMである(71)[総説参照(72)]。N-CAMとN-カドヘリンの発 現パターンは、初期発生の過程で良く似ている(73、74)。最 近、ホメオボックス遺伝子産物がN-CAM遺伝子の転写を直接調 節しうることが示された(75)。N-CAMの発現は神経誘導の直後 の神経上皮細胞に最初に検出され、引き続き短時間の均一な発 現が初期の神経管にみられる。N-カドヘリンと共に、N-CAMは 移動をはじめる神経堤細胞の表層から消失し、感覚神経へ分化 する時に再び現われる。N-CAMはその後、発生過程の神経やグ リアをはじめ、(成体の)筋肉やさまざまな組織に発現する。in vivoやin vitroの摚乱実験から、神経瀻維束発生に抄ける瀻維形 態の維持のような神経の相互作用(76)や、さまざまな神経細胞 
maintenance of fiber topography in developing axon tracts (76), stimulation of neurite outgrowth of a variety of neuronal cell types (see below) and stabilization of cellular and synaptic junctions (77).

Modifications of N-CAM structure may contribute to these various developmental functions (72). Diversity of NCAM structure is generated by alternative splicing which results in the production of several isoforms $(78,79)$. In brain, three major N-CAM polypeptides are produced (N-CAM-180, N-CAM-140 and N-CAM-120) which have identical extracellular domains but differ in the length of their cytoplasmic domains. Whereas N-CAM-180 and N-CAM-140 are integral proteins containing progressively shorter cytoplasmic domains, N-CAM-120 is linked to the plasma membrane by a phospholipid linkage. The expression of these isoforms is developmentally regulated with N-CAM- 180 expression appearing only on postmitotic and postmigratory cells. When expressed in $3 \mathrm{~T} 3$ cells, this isoform has reduced lateral mobility compared to the smaller isoforms $(80,81)$, perhaps due to a specific interaction with a cytoskeletal component. Although this isoform is capable of functioning as a cell adhesion molecule, it exhibits poor ability to promote neurite outgrowth of neurons in culture (82), suggesting functional differences occur as a result of alternative cytoplasmic structures. Cytoskeletal association through ankyrin to the spectrin-based membrane skeleton has been demonstrated for several Ig-like CAMs, namely, neurofascin, $\mathrm{Ll}$ and $\mathrm{NrCAM}(83)$.

Alternative splicing can also change the extracellular domain of N-CAM. N-CAM contains five immunoglobulin domains and two fibronectin type III repeats in its extracellular domain (79). Up to four small exons can alter the structure between the FN III repeats, and a 30 bp exon named VASE (variable alternatively spliced exon) can interrupt the two exons which normally encode the fourth Ig domain of N-CAM. The levels of the VASE containing transcript increase during CNS development, reaching up to $50 \%$ of all N-CAM transcripts in the adult CNS. The extracellular domain is also modified by post-translational modifications. The amount of polysialic acid (PSA) on N-CAM at a given time during development varies among different parts of the nervous system and decreases during development (84). Changes in the state of N-CAM sialylation may account for, in part, the enhanced migration and axon outgrowth properties of N-CAM during embryonic development. Both the use of the VASE exon in N-CAM and a low degree of sialylation, conditions which do not affect or even ameliorate cell adhesion (85), substantially inhibits the ability of N-CAM to promote neurite outgrowth (86). The reciprocal patterns of PSA and VASE expression during development suggest that these alterations may change the function of $\mathrm{N}$ CAM from one that promotes plasticity (migration, neuron outgrowth) to one that promotes stability (adhesion) (87).
種の神経突起伸長の刺激(後述)、細胞間やシナプス間結合の安定 化(77)など、さまざまなN-CAMの役割が示唆されている。

N-CAM構造の修飾はさまざまな発生において発揮する異 なる機能に寄与しうる(72)。N-CAM構造の多様性はオルタナ ティブスプライシングによって生じ、その結果、いくつかの多 型を生じる(78、79)。脳においては、細胞外ドメインは同一で あるが細胞質ドメインは長さが異なる3 種類のN-CAM(N-CAM180、N-CAM-140、N-CAM-120)が主に産生されている。NCAM-180とN-CAM-140が非常に短い細胞質ドメインを有する膜 貫通タンパク質であるのに対して、N-CAM-120はリン脂質結合 によって細胞膜に結合している。これらの多型の発現は分裂や 移動を終了した細胞にのみN-CAM-180を発現することで、発生 過程的な調節を受けている。N-CAM-180を3T3細胞に発現させ た場合、N-CAM-140やN-CAM-120が発現した時と比較すると 側面への移動能が減少するが $(80 、 81) 、$ 抢そらく、細胞骨格の 構成成分と特異的な相互作用をするからであろう。N-CAM-180 は細胞接着分子として機能しうるにもかかわらず、培養下にお いて神経の神経突起伸長の促進能がわずかしかないことは (82)、細胞質ドメインの構造多型の結果として機能の違いが生 じたことが示唆される。スペクトリン系膜骨格とのアンキリン を介した結合は、多くのIg様CAM、すなわちニューロファシ ン、L1やNrCAMによって行われている(83)。

オルタナティブスプライシングはN-CAMの細胞外ドメイ ンも変化させうる。N-CAMはその細胞外ドメインに、5個の免 疫グロブリンドメインと2個のファイブロネクチンタイプIIIリ ピートを有する(79)。4個以下の小さいエクソンが、ファイブロ ネクチンタイプIIIリピートの間の構造を変化させる。また、 $\operatorname{VASE}($ 多様にスプライシングするエクソン)と命名された 30 塩基 対から成るエクンンは、通常N-CAMの4番目のIgドメインを コードする2個のエクソンを中断させる。VASEを含む転写物の 量は中枢神経系の発生に伴って増加し、成体の中枢神経系にお いてはすべてのN-CAMの50\%に達する。細胞外ドメインは転写 後修飾によっても修飾される。発生の時期におけるN-CAMのポ リシアル酸(PSA)含量は神経系の領域によって異なり、発生が進 むにつれて減少する(84)。N-CAMのシアル化状態の変化は、胚 発生の過程のN-CAMによる細胞の移動と神経突起の伸長をある 程度説明できるだろう。N-CAM中にVASEエクソンが発現する ことと、低度のシアル化では、細胞接着に全く影響を与えない か、同等の接着を維持するが(85)、神経突起の伸長促進におけ るN-CAMの能力を十分に阻害する(86)。発生におけるポリシア ル酸とVASEの相反する発現パターンは、可塑性(移動、神経突 起伸長)の促進から、安定性(接着)の促進へと、N-CAMの機能を 変換させうることを示唆する $(87) 。$ 


\section{E. Signal Transduction Pathways Involved in CAM-De- pendent Axonal Growth}

Subsequent to the directed migration of neuronal and glial cells, nervous system development also requires the proper guidance of axons to their correct targets. Navigational decisions in axon targeting are made by the growth cone, the growing tip of the axon. During development of the nervous system, axons reach their target in an appropriate manner, largely governed by CAMs on the neuronal growth cone that bind to CAMs on the surface of other axons or non-neuronal cells, such as astrocytes, muscle cells or Schwann cells $(4,88)$. Originally identified by antibody perturbation experiments, several CAMs, including N-CAM, N-cadherin and the L1 glycoprotein have been implicated in cell-cell contact mediated axonal growth. L1 and N-CAM are both members of the Ig superfamily of CAMs with L1 containing six Ig-like domains and five FN III repeats. In contrast to the broad distribution of $\mathrm{N}-\mathrm{CAM}, \mathrm{L} 1$ expression is restricted to subpopulations of postmitotic neurons in the CNS. L1 is similar to the Ig-like member $\mathrm{NgCAM}$ with respect to structure, distribution and neurite outgrowth promoting activity (89). Whereas neurite outgrowth mediated by N-CAM and L1 are likely to be mediated by homophilic interactions, neurite outgrowth on $\mathrm{NgCAM}$ appears to involve both heterophilic and homophilic mechanisms.

The first insight into the signal transduction mechanisms underlying CAM-dependent neurite outgrowth extended from studies in which cell surface receptors were triggered using specific antibodies directed against N-CAM and Ll on the pheochromocytoma $\mathrm{PC} 12$ cell line. Antibody binding resulted in changes in internal $\mathrm{pH}$, intracellular levels of inositol phosphates and a transient increase in intracellular calcium levels $(90,91)$. This $\mathrm{Ca}^{++}$influx occurred in a pertussis toxininhibitable manner, suggesting the involvement of a $\mathrm{G}$ protein in the transduction process. Currently, pathways involved in CAM signal transduction are being defined by using enhanced neurite outgrowth on a monolayer of CAM transfected or nontransfected fibroblasts as a model system. This technique is more physiologically relevant since the CAM is expressed in appropriate levels, orientation and environment to allow the proper homophilic binding between the CAM on the surface of the neuron and the cell substratum $(88,92)$. A consistent pattern of results emerges using this approach on a variety of neuronal cell types including PC12 cells as well as primary neurons. CAM-dependent neurite outgrowth stimulated by N-CAM, L1 or $\mathrm{N}$-cadherin all involve $\mathrm{Ca}^{++}$as a common second messenger pathway (93-95). Neurite outgrowth on these CAMs can be inhibited by antagonists of $\mathrm{L}$-and $\mathrm{N}$-type $\mathrm{Ca}^{++}$channels or by altering intracellular or extracellular $\mathrm{Ca}^{++}$concentrations. Calcium influx into $\mathrm{PC} 12$ and cerebellar neurons by potassium de-

\section{E. CAM 依存性軸索伸長に必要なシグナル伝達経路}

神経細胞とグリア細胞の指向性のある移動に引き続き、神 経系の発生においては正しい標的に対して神経突起の正確な誘 導を行うことが必要である。神経突起の標的への道筋の決定 は、神経突起の成長端に存在する成長円錐によってなされる。 神経系の発生過程において、神経突起は適切な方法で標的に到 達するが、神経の成長円錐に存在するCAM が、他の神経突起 や、アストロサイト(星状膠細胞)、筋細胞やシュワン細胞などの 非神経細胞のCAMと結合することで、多大に支配される(4、 88)。抗体による擋乱実験によって、N-CAM、N-カドヘリンや L1 糖タンパク質などの多くのCAMは、神経突起の成長を仲介す る細胞-細胞間接着にかかわっていることが明かとなっている。 L1とN-CAMはどちらもCAMのIgスーパーファミリーに属し、 L1は6個のIg様ドメインと5個のファイブロネクチンタイプIIIリ ピートを有する。N-CAMの広い分布に対して、L1は中枢神経系 においては分裂を終了した神経細胞の一部に限定して発現す る。L1は、構造、分布、神経突起伸長增進活性に関して、Ig様 分子の仲間である $\mathrm{NgCAM}$ と類似している(89)。N-CAMとLlに よる神経突起伸長は、ホモフィリックな相互作用を介している のに対して、NgCAMによる神経突起伸長は、へテロフィリック とホモフィリックの両方の機構を必要とする可能性がある。

CAM依存性神経突起伸長の基礎をなすシグナル伝達の機構 の最初の洞察は、クロム親和性細胞腫PC12細胞株のN-CAM と L1に対する特異的な抗体による処理による研究から発展した。 抗体による処理は、細胞内の $\mathrm{pH}$ とイノシトールリン酸量の変 化、細胞内カルシウム量の一過的上昇を引き起こした(90、 91)。このカルシウムイオンの流入は、百日咳毒素で阻害される ことから、シグナル伝達にG多ンパク質の必要性が示唆され た。一般にCAMのシグナル伝達は、モデルシステムとしてCAM を導入した瀻維芽細胞と、導入していない瀻維芽細胞の単層培 養上での神経突起伸長の増強を利用して明らかにされているこ の解析法は、CAMを適切な量、配向、神経と細胞基質の細胞表 層のCAM間の適切なホモフィリックな結合をさせる環境にする ように発現させるので、より生理学的に適切である(88、92)。 PC12細胞をはじめ、さまざまな神経細胞種や初代神経細胞でも 同様に、矛盾のない結果がこの方法を用いて得られている。NCAM、L1やN-カドへリンによるCAM依存性神経突起伸長は、 すべて共通のセカンドメッセンジャーとしてカルシウムイオン を必要とする(93-95)。これらのCAMによる神経突起伸長は、L 型とN型カルシウムイオンチャンネルのアンタゴニストによっ て、もしくは細胞内や細胞外のカルシウムイオンの濃度の変化 によって阻害される。カリウム脱分極によるPC12細胞と小脳神 
polarization can fully mimic the CAM-dependent neurite outgrowth. Pertussis toxin sensitive $\mathrm{G}$ proteins may be involved in regulating $\mathrm{Ca}^{++}$channel function since this agent is capable of inhibiting CAM-dependent neurite outgrowth caused by treatment with CAMs but not that caused by the direct activation of $\mathrm{Ca}^{++}$channels. This suggests that $\mathrm{Ca}^{++}$influx through $\mathrm{L}$-and $\mathrm{N}-$ type $\mathrm{Ca}^{++}$channels is necessary and sufficient for CAM mediated neurite outgrowth. This pathway appears to be specific for CAM-mediated neurite outgrowth (mediated by N-CAM and $\mathrm{N}$-Cadherin or L1) since the above treatments are not capable of inhibiting neurite outgrowth promoted by other CAMs, namely integrins, or other factors such as nerve growth factor (NGF) or cAMP. Interestingly, treatment with physiological levels of NGF in PC12 cells results in induction of both NCAM (96) and N-cadherin (93).

The fact that all three CAMs appear to be capable of activating the same pathway suggest that they may activate a common adaptor or effector molecule upon ligand stimulation. A common element to this pathway is the requirement for a tyrosine kinase(s). In addition to receptor tyrosine kinases for such neurotrophins as FGF and NGF (97), cytoplasmic tyrosine kinases such as $\mathrm{c}$-src have been localized to the growth cone and are expressed at high levels during axon extension (98). N$\mathrm{CAM}$ and $\mathrm{N}$-Cadherin mediated neurite outgrowth can be distinguished from that promoted by other means, such as integrins, by its selective sensitivity to the erbstatin analog tyrosine kinase inhibitor (99). Recently, it has been demonstrated that stimulation of neurite outgrowth elicited by basic FGF involves the activation of a signal transduction pathway that appears to be indistinguishable from that caused by N-CAM, Ncadherin and L1 (100). This pathway is pharmacologically similar to CAM-mediated neurite outgrowth by its sensitivity to erbstatin, by a variety of L- or $\mathrm{N}$ - type calcium channel blockers, and by its sensitivity to a diacylglycerol (DAG) lipase inhibitor. An important event downstream of kinase activation appears to be the conversion of DAG to arachidonic acid by DAG lipase. Arachidonic acid has been shown to activate calcium channels in certain systems and is capable of mimicking the neurite outgrowth response prompted by the effects of treating with $\mathrm{N}-\mathrm{CAM}, \mathrm{N}$-cadherin and $\mathrm{L} 1$. The FGF receptor may be one of the primary effector molecules activated upon CAM binding (101). Binding of CAMs appears to induce the activation of FGF receptor since treatment with either soluble CAM or FGF increases the level of phosphotyrosine in an identical subset of proteins, including the FGF receptor. Interestingly, certain antibodies directed against the FGF receptor are capable of blocking the neurite outgrowth response to CAMs, although neutralizing antibodies or peptides which prevent FGF binding do not. Furthermore, a synthetic peptide directed against a region of the FGF receptor located between the first and second Ig domain, which shares some homology to sequences found in
経へのカルシウム流入は、CAM依存性神経突起伸長をほぼ完全 に模倣できる。百日咳毒素感受性Gタンパク質はCAMの処理に よって引き起こされるCAM依存性神経突起伸長を阻害しうる が、カルシウムイオンチャンネルの直接活性化によって阻害さ れないことから、カルシウムイオンチャンネル機能の調節に必 要であると考えられる。このことより、L型とN型カルシウムイ オンチャンネルを介したカルシウムイオンの流入は、CAMを介 する神経突起伸長に必要かつ十分であることが示唆される。イ ンテグリンや神経成長因子(NGF)やcAMPによる神経突起伸長促 進については、同様な処理を施しても阻害しえないことから、 この経路はCAMを介する神経突起伸長(N-CAM、N-カドへリン もしくはL1を介する)に特異的である。興味深いことに、PC12 細胞を生理学的な濃度のNGFで処理すると、N-CAM(96)とN-カ ドヘリン (93)の両方が誘導される。

すべて3種類のCAMが、同じ経路を活性化することが事実 ならば、共通のアダプターかエフェクター分子がリガンドによ る刺激で活性化されるだろう。この経路の共通の要素はチロシ ンキナーゼを必要とすることである。FGFやNGF(97)のような ニューロトロフィンのレセプターチロシンキナーゼに加えて、 c-srcのような細胞質チロシンキナーゼが成長円錐に局在してお り、神経突起の伸長時に高い発現がみられる(98)。N-CAMとNカドヘリンを介する神経突起伸長は、インテグリンなどによる 神経突起伸長とは、チロシンキナーゼの阻害剤であるアーブス タチンのアナログに撰択的感受性があることで識別されうる (99)。最近、塩基性FGFによって引き起こされる神経突起伸長の 刺激は、N-CAM、N-カドヘリンやL1によって生じるのと区別で きないシグナル伝達経路の活性化を必要としていることが示さ 机た(100)。この経路は、アーブスタチン感受性、L型もしくはN 型カルシウムチャンネルインヒビターによる変化、ジアシルグ リセロール(DAG)リパーゼ阻害剤感受性に関して、CAMを介す る神経突起伸長と類似している。キナーゼ活性化の下流に存在 する重要な事象は、DAGリパーゼによってDAGからアラキドン 酸に変換することであると思わ机る。アラキドン酸はある系に おいてはカルシウムチャンネルの活性化を引き起こし、NCAM、N-カドヘリンやLI処理による効果によって誘導される神 経突起伸長を模做することができる。FGFレセプターは、CAM の結合によって活性化される初期に働く分子の一つらしい (101)。可溶性CAMもしくはFGFの処理によって、FGFレセプ ターのような同一のタンパク質群におけるリン酸化チロシン量 が増加することから、CAMの結合によってFGFレセプターの活 性化が引き起こされるようである。興味深いことに、FGFレ七 プターに対する抗体の幾つかは、CAMによる神経突起伸長を阻 止しうるが、FGF抗体を中和したりぺプチドを加えてFGF結合 を阻害しても伸長は阻止できない。さらに、CAMホモロジード メイン $(\mathrm{CHD})$ と呼ばれるN-CAM、N-カドへリンやL1の細胞外ド 


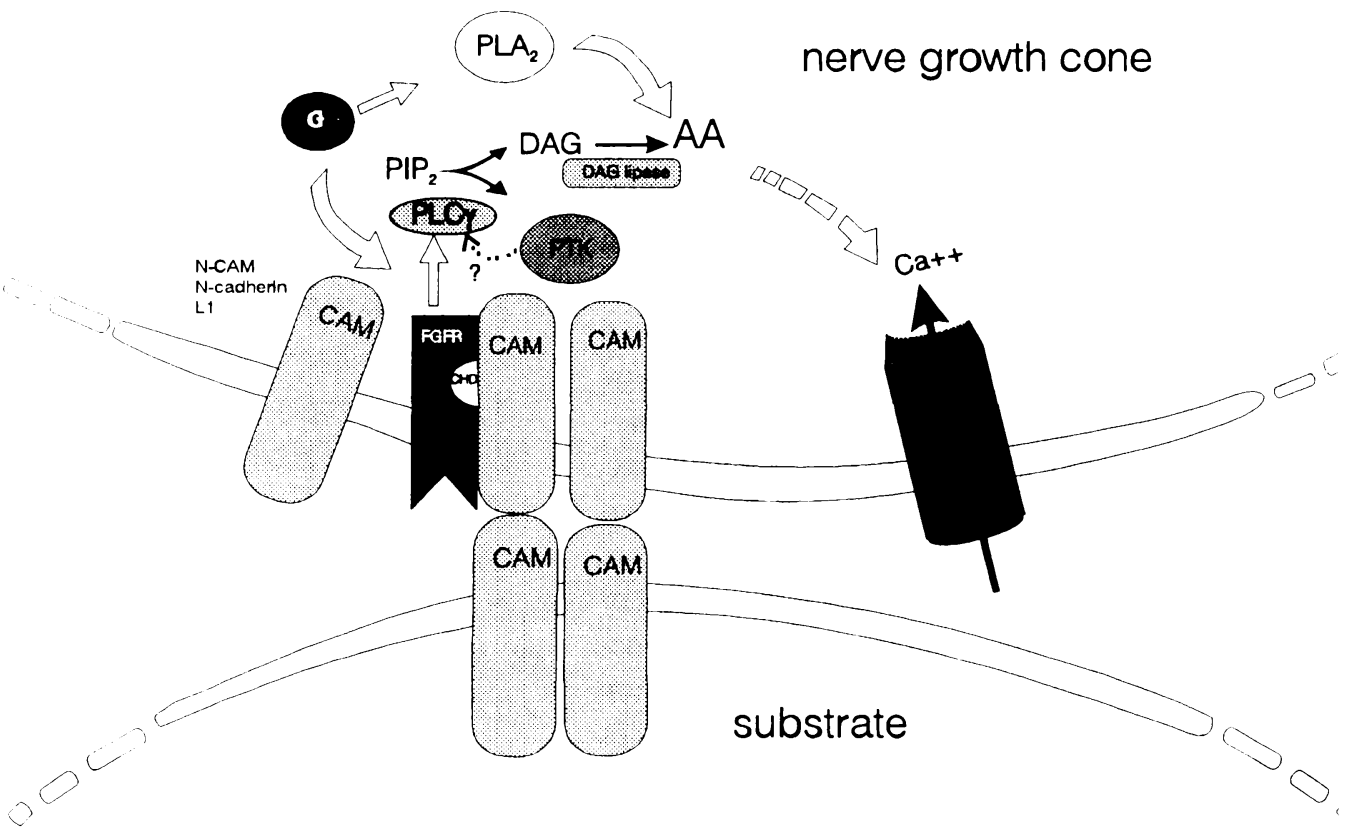

Fig. 2. Schematic of the proposed signal transduction pathway underlying CAM-mediated neuriteoutgrowth [adapted from ref (88)]. Transinteraction of homophilic CAMs on opposing surfaces leads to a cis-interaction between the $\mathrm{CAM}$ and the FGF receptor. This results in activation(tyrosine phosphorylation) of the FGF receptor and downstream activation of downstream effector molecules such as PLC, DAG lipase, heterotrimeric G proteins and phospholipase A2. The final second messenger of CAM binding is believed to be calcium influx, mediated by L-and N-type calcium channels. The role of cytoplasmic tyrosine kinases (PTK), in such as a pathway is currently unclear. See text for details.

the extracellular domains of $\mathrm{N}-\mathrm{CAM}, \mathrm{N}$-cadherin and $\mathrm{L} 1$ called the CAM Homology Domain (CHD) is also capable of blocking the neurite outgrowth response to CAMs. This suggest that FGF receptor. but not FGF, is required for cell-contact dependent neurite outgrowth. The binding of CAMs from the surface of the growth cone to another cell would lead to clustering of CAMs and direct or indirect binding and activation of the FGF receptor (see model, Fig. 2). In addition cytoplasmic tyrosine kinases such as fyn and src are implicated in CAM-directed neurite outgrowth, since cerebellar and dorsal root ganglion neurons obtained from fyn-deficient mice are incapable of extending neurites on N-CAM transfected cells (102). Similarly, cerebellar granule cells from src- mice are impaired in their ability to extend neurites on a LI substrate (103).

\section{F. MAG and Myelination}

Myelination is responsible for the rapid saltatory conduction necessary for efficient nerve transmission in vertebrates. The myelin sheath is formed by Schwann cells in the PNS and oligodendrocytes in the CNS as a specialized extension of the glial cell membrane and results in a concentric multilammelar spiral surrounding the axon [reviewed in ref. (104.105)]. Myelin contains relatively few proteins. The major protein components of CNS myelin are proteolipid protein (PLP) and myelin basic protein (MBP). Whereby MBP mediates compaction between adjacent cytoplasmic surfaces to form the major dense line, PLP, an integral membrane protein is be-
メインに見い出される配列とホモロジーのあるFGFレセプター の第一㧍よび第一. Igドメインの間に位置する領域に相当する合 成ペプチドは、CAMによる神経突起伸長を阻害しうる。これ は、FGFレセプターは細胞間接着依存性神経突起伸長に必要で あるが、FGFは必要でないことを示唆する。成長円錐の細胞表 層から他の細胞へのCAMの結合は、CAMのクラスター形成と FGFレセプターの直接もしくは間接的な結合と活性化を引き起 こす(図2のモデルを参照せよ)。さらに、fyn欠損マウスから得た 小脳や後根神経節の神経細胞は、N-CAMを導入した細胞上で神 経突起を伸長できないこと(102)、また、src欠損マウスから得た 小細の顆粒細胞は、L1 基質上で神経突起の伸長能が損なわ机て

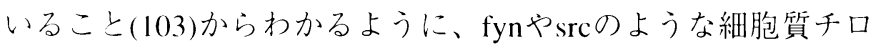
シンキナーゼは、CAMによる神経突起伸長にかかわっているこ とが示唆される。

\section{F. MAGとミエリン化}

ミエリン化によって、㫪椎動物に扔いて有効な神経伝達を 行うために必要な躍進的な伝尊が可能となる。ミエリン鞘は、 グリア細胞膜が特徵的に伸長して神経突起の周辺を緻密な多層 状の螺旋で取り囲む膜のことで、末梢神経ではシュワン細胞、 中枢神経ではオリゴデンドロサイト(希突起膠細胞)が形成する [総説参照 $(104 、 105)$ 。ミエリリンは比較的少数のタンパク質から 構成される。中枢神経系のミエリンの主要構成タンパク質は、 プロテオリピドタンパク質(PLP)とミエリン塩基性タンパク質 (MBP)である。MBPは隣接する細胞質の表面どうしをきっちり 
lieved to mediate interactions between opposing extracellular membranes in the formation of the intraperiod line. In myelin of the PNS, P zero (P0), a member of the Ig superfamily, is the major component and is involved in the associations of extracellular membrane surfaces. MBP is also present, although at lower levels than in the CNS. Several myelination-defective mouse strains (106), such as Jimpy and Shiverer, have been shown to be caused by mutations in PLP and MBP respectively.

In addition to these major proteins which mediate myelin wrapping and compaction, a variety of less abundantly expressed proteins are expressed which participate in the differentiation of glial cells and the initial induction of myelination. Temporal and spatial expression studies suggest that MAG or myelin-associated glycoprotein plays an important role in mediating axon-glia recognition events that precede myelination and define its initiation $(107,108)$. This is supported by studies in which antisense MAG mRNA was shown to inhibit the ensheathment and myelination of neurons in culture (109). However, the phenotype of mice in which the gene for MAG is ablated show only subtle changes in myelin morphology (110, 111), perhaps due to redundancy of MAG function or compensatory mechanisms (112).

MAG is a type 1 integral membrane protein, with an amino-terminal extracellular domain, a single transmembrane domain, and a cytoplasmic carboxyl-terminus (113-116) . MAG is a member of the immunoglobulin (Ig) supergene family and is restricted in expression to oligodendrocytes in the central nervous system and Schwann cells in the peripheral nervous system (117). In its extracellular domain MAG contains five Ig domains and most closely resembles N-CAM. Previous studies have shown that MAG is capable of binding to neurons in culture when reconstituted into liposomes $(118,119)$. Subsequently, work from this laboratory has demonstrated MAG is capable of functioning as a heterophilic cell adhesion molecule when expressed in L-cell fibroblasts (120). Since MAG is not expressed on neurons, binding is believed to be heterophilic, although, the nature of the receptor is not known.

MAG is encoded by a single gene as two developmentally regulated alternatively spliced isoforms $(113,114,116$, 121). They are designated L-MAG (for large MAG) and SMAG (for small MAG) and have molecular masses of $72 \mathrm{kDa}$ and $67 \mathrm{kDa}$, respectively, in their nonglycosylated forms. The MAG isoforms are identical in their extracellular and transmembrane domains and share a common region in their cytoplasmic domain, but are distinct at their carboxyl termini. In vivo and in vitro studies show that MAG is phosphorylated mainly on serine, but also to some extent on threonine and tyrosine residues $(122,123)$. We have previously shown that both L-MAG and S-MAG isoforms are phosphorylated when expressed in heterologous cells in culture (123). Whereas LMAG is phosphorylated on serine and tyrosine residues, S-
と緅じ合わせて主要な層とし、膜貫通タンパク質であるPLPは 中間層の形成において対をなす細胞外の膜の間の相互作用を仲 介寸ると考えられている。Igスーパーファミリーに属するPゼロ (P0)は末梢神経系ミエリンの主要成分であり、細胞膜表層の結 合に必要である。MBPは末梢神経系にも存在するが、中枢神経 系と比較するとその量はわずかである。JimpyやShivererのよう なミエリン化欠損マウスは、PLPとMBPの変異によって引き起 こされることが示されている(106)。

ミエリンによる包み込み(ラッピング)と圧縮(コンパクショ ン)を媒介する上記の主要なタンパク質に加えて、発現は多くは ないがグリア細胞の分化とミエリン化の初期誘導にかかわる沢 山のタンパク質が発現する。時間的、空間的な発現解析の結 果、MAG、すなわち、ミエリン結合性糖タンパク質は、ミエリ ン化に先立ち、その開始を明確にする軸索ーグリア認識過程にお いて重要な役割を担っていることが示唆された(107、108)。こ れは、アンチセンスMAGmRNAが、培養神経細胞の鞘での被覆 とミエリン化を阻害することを示した研究から支持される (109)。しかし、MAGの遺伝子を除去されたマウスの表現型で は、ミエリンの形態が微妙に変化しただけだった(110、111)。 これはおそらく、MAGの機能が過剩であるか、補償する機構が あるためであろう(112)。

MAGは1型膜貫通タンパク質で、アミノ末端である細胞外 ドメイン、1つの膜貫通ドメイン、細胞質のカルボキシ末端から 構成される(113-116)。MAGは免疫グロブリン(Ig)スーパーファ ミリーに属し、中枢神経系ではオリゴデンドロサイト、末梢神 経系ではシュワン細胞に発現が限局している(117)。MAGの細胞 外ドメインは5個のIgドメインを含み、N-CAMと非常に良く類 似している。以前の研究より、MAGをリポソームに再構成する と、培養神経細胞に結合しうることが示されている(118、 119)。その後の当研究室の研究で、MAGをL繊維芽細胞に発現 させると、へテロフィリックな細胞接着分子として機能しうる ことが示された(120)。MAGは神経細胞に発現していないことか らこの結合はへテロフィリックと考えられるが、そのレセプ ターの正体はわかっていない。

MAGでは、2つの発生過程で制御されるスプライシングア イソフォームが、1つの遺伝子上にコードされている(113、 114、116、121)。その糖の付いていないアイソフォームは、72 $\mathrm{kDa}$ の分子が、 $\mathrm{L}-\mathrm{MAG}$ (大型MAG)、67 kDaの分子がS-MAG(小 型MAG) と名付けられている。MAGのアイソフォームはその細 胞外と膜貫通ドメインは同一であり、細胞質ドメインの一部は 共通の領域があるが、そのカルボキシ末端で異なっている。in vivoとin vitroの研究によって、MAGは主にセリンがリン酸化さ れるが、スレオニンやチロシン残基もある程度りン酸化される (122、123)。以前に我々は、L-MAGとS-MAGのアイソフォーム が、異種の培養細胞に発現させたときにリン酸化されることを 示した(123)。L-MAGではセリンとチロシン残基がリン酸化さ机 
MAG is constitutively phosphorylated only on serine. The early appearance of L-MAG at the onset of myelination and its differential phosphorylation suggest a role for tyrosine phosphorylation in the initial process of neuron recognition and signal transduction.

We have identified Tyr 620 as the major tyrosine phosphorylation site of MAG expressed in oligodendrocytes (124). The site, which is not present in S-MAG, when phosphorylated is capable of binding the $\mathrm{SH} 2$ domains of PLC in vitro. This association occurs between endogenously (from brain extracts) or exogenously (in transfected cells) expressed L-MAG and, PLC $\gamma$ suggesting that such an association is physiologically significant in vivo. L-MAG may function in an analogous fashion to a growth factor receptor. Tyrosine phosphorylation of LMAG and its subsequent association with $\mathrm{SH} 2$ containing proteins, such as PLC, may act to transduce an extracellular signal necessary for the initiation of myelination.

Analysis of this sequence reveals an interesting homology with other Ig related cell adhesion molecules. As shown in Table I, the carboxyl terminal 8 amino acids, EYAEIRVK, are identical to the terminal residues identified in the recently cloned Schwann cell myelin protein (SMP)(125) and highly homologous to carboxyl regions in other molecules such as CD22(126, 127), CD33 (128), CD31 [platelet-endothelial cell adhesion molecule-1 or PECAM-1 (129)] and BGP [ biliary glycoprotein (130)]. Of these molecules, BGP(130) and CD22 (131) have been shown to be phosphorylated on tyrosine residues thus far. Other cell surface adhesion molecules are known to interact with cytoplasmic PTKs in well characterized transmembrane signalling pathways. The in vivo significance of this finding is currently unknown, however, MAG, BGP, SMP, $\mathrm{CD} 33, \mathrm{CD} 22$ and CD31 may encompass a group of cell adhesion molecules that are involved in a signal transduction system, possibly involving PLC $\gamma$. In the case of MAG, this signalling pathway is regulated by differential isoform expression
ているのに対して、S-MAGではセリン残基のみが構成的にリン 酸化されている。ミエリン化の開始に伴うL-MAGの出現とその リン酸化の変化は、神経細胞の認識とシグナル伝達の初期段階 におけるチロシンリン酸化の役割を示唆する。

我々は、オリゴデンドロサイトに発現するMAGの主要なチ ロシンリン酸化部位は620残基目のチロシンであることを同定し た(124)。S-MAGには存在しないこのリン酸化部位がリン酸化さ れていると、in vitroにおいてPLC $\gamma$ のSH2ドメインと結合しう る。この結合は内在性(脳の抽出物)や外来性(遺伝子導入細胞)に 発現したL-MAGとPLC $\gamma$ との間に起こるので、このような結合 はin vivoにおける生理学的な意義を示唆している。L-MAGは成 長因子レセプターと似た様式で機能するらしい。L-MAGのチロ シンリン酸化と、それに引き続くPLCのようなSH2ドメインを 含むタンパク質との結合は、ミエリン化の開始に必要な細胞外 シグナルの伝達として働くであろう。

L-MAGの構造解析の結果、他のIg関連細胞接着分子と興味 深い相同性の存在が明かとなった。表Iに示す通り、カルボキシ 末端の8アミノ酸(EYAEIRVK)は最近クローン化されたシュワン 細胞ミエリンタンパク質(SMP)(125)のカルボキシ末端と同一で あり、CD22(126、127)、CD33(128)、CD31 [血小板-上皮細胞接 着分子-1もしくはPECAM-1(129)]そしてBGP [胆汁糖タンパク質 (130)]のような他の分子のカルボキシル末端部位と高い相同性を 示した。このうち BGP(130)やCD22(131)ではチロシン残基がリ ン酸化されていることが示されている。その他の細胞接着分子 は、詳細に記述されている膜貫通シグナル伝達経路に存在する 細胞質PTKと相互作用することが知られている。しかし、この 知見のin vivoにおける重要性は今のところ解からないが、 MAG、BGP、SMP、CD33、CD22やCD31は、PLC $\gamma$ をおそら く含むシグナル伝達系を必要とする細胞接着分子群に属すると 思われる。MAGの場合このシグナル伝達経路は、発生過程にお

Table I. Homologies of carboxyl terminal amino acids in several Ig related CAMs.

\begin{tabular}{ll}
\hline Molecule & $\begin{array}{c}\text { Carboxy terminal amino } \\
\text { acid sequence }\end{array}$ \\
\hline L-MAG & EYAEIRVK \\
SMP & EYAEURVK \\
BGP & IYSEVKKQ \\
CD22 & HYSELIQ \\
CD33 & EYSEVRTQ \\
CD31 & VYSEVRKA \\
\hline
\end{tabular}

Amino acid residues 619-626 in L-MAG were compared to residues: 614-621 in SMP (125); 520-527 in BGP(130); 821-828 in CD22 (126,127); 357-364 in CD33 (128); 685692 in CD31 (129). 
Fig. 3. Schematic for proposed model of MAG activation of myelination. Fyn binds constitutively to MAG in a latent form. Binding to the MAG receptor on the surface of an axon would transduce a conformational change in $\mathrm{L}$ MAG, resulting in activation of Fyn kinase and phosphorylation of Tyr 620. Binding and activation of PLC $\gamma$ (and/or other effector molecules) would contribute to the signalling pathway involved in the regulation of myelination. See text for details.

during development( $(115,132)$.

Another signal transducing molecule which binds to MAG is the Fyn tyrosine kinase. We found that, unlike PLC $\gamma$, Fyn is capable of interacting with both L- and S-MAG isoforms. Although both $\mathrm{SH} 2$ and $\mathrm{SH} 3$ domains appear to be necessary for high affinity Fyn binding (124) and kinase activity (133), binding can also occur in an SH2-independent manner. This is reminiscent of the B-cell receptor-Fyn kinase interaction, in which association of the tyrosine phosphorylated and non-phosphorylated forms of Ig- $\alpha$ occurs via distinct regions of the Fyn kinase (134). Moreover, it has been documented that only the high affinity SH2-mediated interaction of Fyn with Ig$\alpha$ stimulates kinase activity (135). It may be that although Fyn can bind both MAG isoforms, it becomes activated only when complexed to L-MAG. Consistent with this is the observation that antibody cross-linking of L-MAG but not S-MAG causes an increase in Fyn kinase activity (133). Fyn association is believed to be physiologically relevant since mice in which the gene for fyn is ablated have impaired myelination (133).

These results demonstrate that MAG interacts with PLC $\gamma$ and Fyn through different sites. Taken together, these observations as well as those of others (133), suggest a model (Fig. 3) wherein Fyn binds constitutively to MAG in a latent form. Ligand stimulation of L-MAG would result in activation of Fyn kinase and phosphorylation of Tyr 620. Binding and activation of PLC $\gamma$ through this phosphotyrosine residue would contribute to the signalling pathway involved in the regulation of myelination. axon

MAG receptor
けるアイソフォームの発現の違いによって制御されている (115,132)。

MAGに結合する別のシグナル伝達分子はFynチロシンキ ナーゼである。Fynは、PLC $\gamma$ とは異なり、L-MAGとS-MAGの 両方と相互作用しうることを我々は発見した。SH2とSH3ドメイ ンの両方が、高親和性Fyn結合(124)とキナーゼ活性(133)のため に必要であるにもかかわらず、SH2 非依存性の結合も起こり得 る。これは、B細胞レセプター-Fynキナーゼ相互作用における、 Fynキナーゼの特定の領域を介して起こるIg- $\alpha$ のチロシンリン 酸化と非リン酸化型の結合を暗示する(134)。さらに、高親和性 SH2を介在するFynとIg- $\alpha$ の相互作用だけが、キナーゼ活性を刺 激することが証明されている(135)。FynはMAGの両方のアイソ フォームと結合しうるが、L-MAGと複合体を形成したときにの み活性化するのだろう。L-MAGをクロスリンクさせる抗体は Fynキナーゼ活性を上昇させるが、S-MAGの場合そのようなこ とは起こらないことは、先の結果と矛盾しない(133)。Fynの遺 伝子を除去したマウスではミエリン化が損なわれることから、 Fynの結合は生理学的に意味のあるものと考えられている (133)。

これらの結果は、MAGは異なる部位でPLC $\gamma$ とFynと相互 作用していることを証明するものである。これらの知見とそれ 以外の結果(133)と合わせて考えると、Fynが潜在型MAGと構成 的な結合をすることに関するモデルが示唆される(図3)。L-MAG のリガンドの刺激の結果、Fynキナーゼを活性化し、620残基目 のチロシンのリン酸化を引き起こす。このリン酸化チロシンを 介したPLC $\gamma$ の結合と活性化が、ミエリン化の調節に必要なシ グナル伀達経路に寄与しているのだろう。 


\section{Acknowledgments}

Thanks to Peter Duncan and Ninan Abraham for helpful suggestions in writing this manuscript. This work was supported by a grant from the Medical Research Council of Canada and the National Cancer Institute of Canada (NCIC). J.C.B. is an NCIC Senior Scientist. M.L.J. is a postdoctoral fellow of the Medical Research Council of Canada.
東京工業大学·生命理工学部·生体分子工学科

糖鎖生命科学講座

日向 晶司訳

\section{References}

1. Greenwald, I., and Rubin, G.M. (1992) Cell 68, 271-281

2. Jessel, T.M. (1988) Neuron 1, 3-13

3. Hynes, R.O., and Lander, A.D. (1992) Cell 68, 303-322

4. Goodman, C.S., and Shatz, C.J. (1993) Cell 72, 77-98

5. Takeichi, M. (1991) Science 251, 1451-1455

6. Hynes, R.O. (1992) Curr. Opin. Genet. Dev. 2, 621-624

7. Grunwald, G.B. (1993) Curr. Opin. Cell Biol. 5, 797-805

8. Rathjen, F.G. (1991) Curr. Opin. Cell Biol. 3, 992-1000

9. Inuzuka, H., Miyatani, S., and Takeichi, M. (1991) Neuron 7, 69-79

10. Napolitano, E.W., Venstrom, K., Wheeler, E.F., and Reichardt, L.F. (1991) J. Cell Biol. 113, 893-905

11. Suzuki, S., Sano, K., and Tanihara, H. (1991) Cell Regulation 2, 261-270

12. Nose, A., Nagafuchi, A., and Takeichi, M. (1988) Cell 54, 993-1001

13. Takeichi, M. (1988) Development 102, 639-655

14. Ranscht, B. (1994) Curr. Opin. Cell Biol. 6, 740-746

15. Fleming, T.P., and Johnson, M.H. (1988) Annu. Rev. Cell Biol. 4, 459-485

16. Nagafuchi, A., Tsukita, S., and Takeichi, M. (1993) Seminars in Cell Biol. 4, 175-181

17. Nose, A., Tsuji, K., and Takeichi, M. (1990) Cell 61, 147-155

18. Nagafuchi, A., and Takeichi, M. (1988) EMBO J. 7, 3679-3684

19. Ozawa, M., Ringwald, M., and Kemler, R. (1990) Proc. Natl. Acad. Sci. USA 87, 4246-4250

20. Ozawa, M. and Kemler, R. (1992) J. Cell Biol. 116, 989-996

21. Levine, E., Lee, C.-H., Kintner, C., and Gumbiner, B.M. (1994) Development 120, 901-909

22. Kintner, C. (1992) Cell 69, 225-236

23. Gumbiner, B. (1993) Neuron 11, 551-564

24. Hirano, S., Kimoto, N., Shimoyama, Y., Hiroshashi, S., and Takeichi, M. (1992) Cell 70, 293-301

25. McCrea, P.D., Turck, C.W., and Gumbiner, B. (1991) Science 254, 1359-1361

26. Hinck, L., Näthke, I.S., Papkoff, J., and Nelson, W.J. (1994) Trends Biochem. Sci. 19, 538-542

27. Klingensmith, J., and Nusse, R. (1994) Dev. Biol. 166, 396-414

28. Hinck, L., Nelson, W.J., and Papkoff, J. (1994) J. Cell Biol. 124, 729-741

29. Rubinfeld, B., Souza, B., Albert, I., Muller, O., Chamberlain, S.H., Masiarz, F.R., Munemitsu, S., and Polakis, P. (1993) Science 262, 17311734

30. Su, L-K., Vogelstein, B., and Kinzler, K.W. (1993) Science 262, 1734-1737

31. Hulsken, J., Behrens, J., and Birchmeier, W. (1994) Curr. Opin. Cell Biol. 6, 711-716

32. Edelman, G.M. (1994) Progress in Brain Research 101, 1-14

33. Hamaguchi, M., Matsuyoshi, N., Ohnishi, Y., Gotoh, B., Takeichi, M., and Nagai, Y. (1993) EMBO J. 12, 307-314

34. Matsuyoshi, N., Hamaguchi, M., Taniguchi, S., Nagafuchi, A., Tsukita, S., and Takeichi, M. (1992) J. Cell Biol. 118, 703-714

35. Shibamoto, S., Hayakawa, M., Takeuchi, K., Hori, T., Oku, N., Miyazawa, K., Kitamura, N., Takeichi, M., and Ito, F. (1994) Cell Adhesion Commun. 1, 295-305

36. Hoschuetzky, H., Aberle, H., and Kemler, R. (1994) J. Cell Biol. 127, 1375-1380

37. Hynes, R.O. (1987) Cell 48, 549-554

38. Hynes, R.O. (1992) Cell 69, 11-25

39. Springer, T.A. (1990) Nature 346, 425-434

40. Yamada, K.M. (1991) J. Biol. Chem. 266, 12809-12812

41. Haas, T.A., and Plow, E.F. (1994) Curr. Opin. Cell Biol. 6, 656-662

42. Ruoslahti, E. and Pierschbacher, M.D. (1987) Science 238, 491-497

43. DeSimone, D.W. (1994) Curr. Opin. Cell Biol. 6, 747-751

44. Adams, J.C., and Watt, F.M. (1993) Development 117, 1183-1198

45. Letourneau, P.C., Condic, M.L., and Snow, D.M. (1992) Curr. Opin. Genet. Dev. 2, 625-634

46. Ginsberg, M.H., Du, X., and Plow, E.F. (1992) Curr. Opin. Cell Biol. 4, 766-771

47. Shattil, S.J., Ginsberg, M.H., and Brugge, J.S. (1994) Curr. Opin. Cell Biol. 6, 695-704

48. Larson, R.S., and Springer, T.A (1990) Immunol. Rev. 114, 181-217

49. O’Toole, T.E., Mandelman, D., Forsyth, J., Shattil, S.J., Plow, E.F., and Ginsberg, M.H. (1991) Science 254, 845-847

50. Turner, C.E. and Burridge, K. (1991) Curr. Opin. Cell Biol. 3, 849-853

51. Burridge, K., Turner, C.E., and Romer, L.H. (1992) J. Cell Biol. 119, 893-903 
Trends in Glycoscience and Glycotechnology Vol. 7 No. 35 (May 1995) pp. 205-221

52. Guan, J.-L., and Shalloway, D. (1992) Nature 358, 690-692

53. Giancotti, F.G., and Mainiero, F. (1994) Biochim. Biophys. Acta 1198, 47-64

54. Damsky, C.H., and Werb, Z. (1992) Curr. Opin. Cell Biol. 4, 772-781

55. Juliano, R.L., and Haskill, S. (1993) J. Cell Biol. 120, 577-585

56. Sastry, S.K., and Horwitz, A.F. (1993) Curr. Opin. Cell Biol. 5, 819-831

57. Birge, R.B., Fajardo, J.E., Reichman, C., Shoelson, S.E., Songyan, Z., Cantley, L.C., and Hanafusa, H. (1993) Mol. Cell. Biol. 13, 46484656

58. Hempstead, B.L., Birge, R.B., Fajardo, J.E., Glassman, R., Mahadeo, D., Kraemer, R., and Hanafusa, H. (1994) Mol. Cell. Biol. 14, 19641971

59. Schaller, M.D., and Parsons, J.T. (1994) Curr. Opin. Cell Biol. 6, 705-710

60. Zachary, I., and Rozengurt, E. (1992) Cell 71, 891-894

61. Guadagno, T.M., Ohtsubo, M., Roberts, J.M., and Assoian, R.K. (1993) Science 262, 1572-1575

62. Ruoslahti, E., and Reed, J.C. (1994) Cell 77, 477-478

63. Schlaepfer, D.D., Hanks, S.K., Hunter, T., and van der Geer, P. (1994) Nature 372, 786-791

64. Morino, N., Mimura, T., Hamasaki, K., Tobe, K., Ueki, K., Kikuchi, K., Takehara, K., Kadowaki, T., Yazaki, Y., and Nojima, Y. (1995) J. Biol. Chem. 270, 269-273

65. Schwartz, M.A. (1993) J. Cell Biol. 120, 1003-1010

66. McNamee, H.P., Ingber, D.E., and Schwartz, M.A. (1993) J. Cell Biol. 121, 673-678

67. Weiss, A. (1993) Cell 73, 209-212

68. Williams, A.F. (1987) Immunol. Today 8, 298-303

69. Williams, A.F., and Barclay, A.N. (1988) Annu. Rev. Immunol. 6, 381-405

70. Buck, C.A. (1992) Seminars in Cell Biol. 3, 179-188

71. Hoffman, S., Sorkin, B.C., White, P.C., Brackenbury, R., Mailhammer, R., Rutishauser, U., Cunningham, B.A., and Edelman, G.M. (1982) J. Biol. Chem. 257, 7720-7729

72. Goridis, C., and Brunet, J.-F. (1992) Seminars in Cell Biol. 3, 189-197

73. Edelman, G.M. (1986) Annu. Rev. Cell Biol. 2, 81-116

74. Rutishauser, U. (1986) Trends in Neurosci. 9, 374-378

75. Jones, F.S., Prediger, E.A., Bittner, D.A., DeRobertis, E.M., and Edelman, G.M.(1992) Proc. Natl. Acad. Sci. USA 89, 2086-2090

76. Fraser, S.E., Carhart, M.S., Murray, B.A., Chuong, C.M., and Edelman, G.M. (1988) Dev. Biol. 129, 217-230

77. Rutishauser, U., Grumet, M., and Edelman, G.M. (1983) J. Cell Biol. 97, 145-152

78. Cunningham, B.A., Hemperly, J.J., Murray, B.A., Prediger, E.A., Brackenbury, R., and Edelman, G.E. (1987) Science 236, 799-806

79. Walsh, F.S., and Doherty, P. (1991) Semin. Neurosci. 3, 271-284

80. Pollerberg, G.E., Schachner, M., and Davoust, J. (1986) Nature 324, 462-265

81. Pollerberg, G.E., Burridge, K., Krebs, K.E., Goodman, S.R., and Schachner, M. (1987) Cell Tissue Res. 250, 227-236

82. Doherty, P., Rimon, G., Mann, D.A., and Walsh, F.S. (1992) J. Neurochem. 58,2338-2341

83. Davis, J.Q., and Bennett, V. (1994) J. Biol. Chem. 269, 27163-27166

84. Rothbard, J.B., Brackenbury, R., Cunningham, B.A., and Edelman, G.M. (1982) J. Biol. Chem. 257, $11064-11069$

85. Hoffman, S., and Edelman, G.M. (1983) Proc. Natl. Acad. Sci. USA 80, 5762-5766

86. Doherty, P., Moolenaar, C.E.C.K., Ashton, S.V., Michalides, R.J.A.M., and Walsh, S. (1992) Nature 356, $791-793$

87. Doherty, P., and Walsh, F.S. (1992) Curr. Opin. Neurobiol. 2, 595-601

88. Doherty, P., and Walsh, F.S. (1994) Curr. Opin. Neurobiol. 4, 49-55

89. Grumet, M. (1992) J. Neurosci. Res. 31, 1-13

90. Schuch, U., Lohse, M.J., and Schachner, M. (1989) Neuron 3, 13-20

91. Von Bohlen und Halbach, F., Taylor, J., and Schachner, M. (1992) Eur. J. Neurosci. 4, 896-909

92. Walsh, F.S., and Doherty, P. (1993) Curr. Opin. Cell Biol. 5, 791-796

93. Doherty, P., Ashton, S.V., Moore, S.E., and Walsh, F.S. (1991) Cell 67, 21-33

94. Saffell, J.L., Walsh, F.S., and Doherty, P. (1992) J. Cell Biol. 118, 663-670

95. Williams, E.J., Doherty, P., Turner, G., Reid, R.A., Hemperly, J.J., and Walsh, F.S.(1992) J. Cell Biol. 119, 883-892

96. Doherty, P., Mann, D.A., and Walsh, F.S. (1988) J. Cell Biol. 107, 333-340

97. Chao, M.V. (1992) Neuron 9, 583-593

98. Maness, P.F., and Cox, M.E. (1992) Sem. Cell Biol. 3, 117-126

99. Williams, E.J., Walsh, F.S., and Doherty, P. (1994) J. Cell Biol. 124, 1029-1037

100. Williams, E.J., Furness, J., Walsh, F.S., and Doherty, P. (1994) Development 120, 1685-1693

101. Williams, E.J., Furness, J., Walsh, F.S., and Doherty, P. (1994) Neuron 13, 583-594

102. Beggs, H.E., Soriano, P., and Maness, P.F. (1994) J. Cell Biol. 127, 825-833

103. Ignelzi, M.A., Miller, D.R., Soriano, P., and Maness, P.F. (1994) Neuron 12, 873-884

104. Doyle, J.P., and Colman, D.R. (1993) Curr. Opin. Cell Biol. 5, 779-785

105. Lemke, G. (1988) Neuron 1, 535-543

106. Nave, K.-A. (1994) J. Neurosci. Res. 38, 607-612

107. Trapp, B.D. (1988) J. Cell Biol. 107, 675-685

108. Trapp, B.D. (1990) Ann. New York Acad. Sci. 605, 29-43

109. Owens, G.C., and Boyd, C.J. (1991) Development 112, 639-649

110. Montag, D., Giese, K.P., Bartsch, U., Martini, R., Lang, Y., Blüthmann, H., Karthigasan, J., Kirschner, D.A., Wintergerst, E.S., Nave, K.-A., Zielasek, J., Toyka, K.V., Lipp, H.-P., and Schachner, M. (1994) Neuron 13, 229-246

111. Li, C., Tropak, M.B., Gerlai, R., Clapoff, S., Abramow-Newerly, W., Trapp, B., Peterson, A., and Roder, J. (1994) Nature 369, 747-750 
112. Meyer-Franke, A., and Barres, B. (1994) Curr. Biol. 4, 847-850

113. Arquint, M., Roder, J., Chia, L.-S., Down, J., Wilkinson, D., Bayley, H., Braun, P.E., and Dunn, R. (1987) Proc. Natl. Acad. Sci. USA 84, 600-604

114. Lai, C., Brow, M.A., Nave, K.-A., Noronha, A.B., Quarles, R.A., Bloom, F.E., Milner, R.J., and Sutcliffe, J.G. (1987) Proc. Natl. Acad. Sci. USA 84, 4337-4341

115. Pedraza, L., Frey, A.B., Hempstead, B.L., Colman, D.R., and Salzer, J.L. (1991) J. Neurosci. Res. 29, 141-148

116. Salzer, J., Holmes, P.W., and Colman, D.R. (1987) J. Cell Biol. 104, 957-965

117. Higgins, G.A., Schmale, H., Bloom, F.E., Wilson, M.C., and Milner, R.J. (1989) Proc. Natl. Acad. Sci. USA 86, 2074-2078

118. Poltorak, M., Sadoul, R., Keilhauer, G., Landa, C., Fahrig, T., and Schachner, M.(1987) J. Cell Biol. 105, $1893-1899$

119. Sadoul, R., Fahrig, T., Bartsch, U., and Schachner, M. (1990) J. Neurosci. Res. 25, 1-13

120. Afar, D.E.H., Marius, R.M., Salzer, J.L., Stanners, C.P., Braun, P.E., and Bell, J.C.(1991) J. Neurosci. Res. 29, 429-436

121. D'Eustachio, P., Colman, D.R., and Salzer, J.L. (1988) J. Neurochem. 50, 589-593

122. Edwards, A.M., Arquint, M., Braun, P.E., Roder, J.C., Dunn, R.J., Pawson, T., and Bell, J.C. (1988) Mol. Cell. Biol. 8, 2655-2658

123. Afar, D.E.H., Salzer, J.L., Roder, J., Braun, P.E., and Bell, J.C. (1990) J. Neurochem. 55, 1418-1426

124. Jaramillo, M.L., Afar, D.E.H., Almazan, G., and Bell, J.C. (1994) J. Biol. Chem. 269, 27240-27245

125. Dulac, C., Tropak, M.B., Cameron-Curry, P., Rossier, J., Marshak, D.R., Roder, J., and Le Douarin, N.M. (1992) Neuron 8, $323-334$

126. Stamenkovic, I., and Seed, B. (1990) Nature 345, 74-77

127. Wilson, G.L., Fox, C.H., Fauci, A.S., and Kehrl, J.H. (1991) J. Exp. Med. 173, 137-146

128. Simmons, D., and Seed, B. (1988) J. Immunol. 141, 2797-2800

129. Kaplan, D.R., Morrison, D.K., Wong, G., McCormick, F., and Williams, L.T. (1990) Cell 61, 125-133

130. Afar, D.E.H., Stanners, C.P., and Bell, J.C. (1992) Biochim. Biophys. Acta 1134, 46-52

131. Schulte, R.J., Campbell, M.A., Fischer, W.H., and Sefton, B.M. (1992) Science 258, 1001-1004

132. Tropak, M.B., Johnson, P.W., Dunn, R.J., and Roder, J.C. (1988) Mol. Brain Res. 4, 143-155

133. Umemori, H., Sato, S., Yagi, T., Aizawa, S., and Yamamoto, T. (1994) Nature 367, 572-576

134. Pleiman, C.M., Abrams, C., Timson Gauen, L., Bedzyk, W., Jongstra, J., Shaw, A.S., and Cambier, J.C. (1994) Proc. Natl. Acad. Sci. USA 91, 4268-4272

135. Clark, M.R., Johnson, S.A., and Cambier, J.C. (1994) EMBO J. 13, 1911-1919

Received on March 10, 1995, accepted on March 21, 1995 